ks. Józef Budniak

Uniwersytet Ślaski w Katowicach

\title{
Ekumenizm na Śląsku Cieszyńskim z perspektywy końca XX stulecia i początku XXI wieku ${ }^{1}$
}

\section{ECUMENISM IN CIESZYN SILESIA SEEN FROM THE PERSPECTIVE OF THE END OF $20^{\text {TH }}$ CENTURY AND THE BEGINNING OF $21^{\text {ST }}$ CENTURY}

Over the years from 16th century up to our times, Protestants, Catholics and Jews lived peacefully together in the region of Cieszyn Silesia. At the beginning of the third millenium one can follow the words of the Swiss Reformed theologian, Karl Barth, that "although we believe otherwise, we don't belive in another God". According the the words everybody's religion and values must be respected.

Cieszyn Sliesia has always been associated with everything what is Christian. For centuries it has been the cradle of faith and the love for God. Cieszyn, as the capital of the region, is a town in which ecumenism - not the theological, but the everyday, practical one - makes sense of people's lives. Due to historical conditions, this land was rich in clergy and lay people for whom the welfare of other human beings, help for those in need, the social, economical and intellectual developement of the capital town were matters of overriding importance. Today - tradition, history, cultural and intellectual heritage connected with this town speak clearly to everybody. The inhabitants of this land value in a really special way the great gift of unity which was given to them in the spirit of God's love. No social or cultural activity is impossible here thanks

Temat ten jest realizacją projektu badawczego (grant) nr: UMO-2014/13/B/ HS5/01482. 
to the true engagement of Catholics and Protestants who are motivated by dialogu the idea of developement of this magic place.

In Cieszyn Silesia, where "ecumenism is the matter of social life", the ecumenical awarness is more and more promoted. It can easily be said that the region, in terms of its ecumenical activity in all its dimensions (spiritual, intellectual, pastoral and practical), could be a guiding light for Europe..

Key words: Cieszyn Silesia, Bielsko-Żywiec diocese, ecumenism, ecumenic initiatives, Roman Catholic Church, Evangelical Church of the Augsburg Confession.

Ruch ekumeniczny - rozwijający się od Soboru Watykańskiego II, a szczególnie za pontyfikatu papieża Jana Pawła II - obejmuje swym zasięgiem trzy płaszczyzny życia Kościoła Powszechnego: duchową, naukowo-popularyzatorską i praktyczną (społeczno-kulturową).

Drogą i celem ekumenizmu jest nie tylko wzajemne poznanie się, wspólna modlitwa, lecz również potrzeba podjęcia współpracy między chrześcijanami na różnych płaszczyznach: duszpasterskiej, kulturowej, społecznej, jak również na dawaniu wspólnego świadectwa w zwiastowaniu Ewangelii „,w myśl zasady, że tego, co można zrobić wspólnie, nie należy czynić samemu"2. To właśnie w takim ujęciu znajduje się m.in. ekumenizm pastoralny, w którym niemałe znaczenie posiada praktyczny ekumenizm, który również wybiega poza pastoralny wymiar. „Pastoralne inicjatywy” to termin, który implikuje refleksje z zakresu teologii pastoralnej, czyli teorii pasterzowania w Kościele, pastoralnych działań, a także realizowania dzieła pojednania w codziennej praktyce. Jest to teologia pracy duszpasterskiej, której podstawę stanowi polecenie dane przez Jezusa Chrystusa Apostołom: „Idźcie na cały świat i głoście Ewangelię wszelkiemu stworzeniu!" (Mk 16, 15). Pastoralny aspekt i motyw działania jest istotny we wszystkich zadaniach i okolicznościach, w jakich Kościół działa. Zadania te można podzielić na dwie części: liturgiczną i pedagogiczną (dydaktyczno-wychowawczą) ${ }^{3}$.

Podstawowe funkcje działania pastoralnego to:

- prorocka - posługa Słowa Bożego (ewangelizacja, katechizacja, przepowiadanie homiletyczne);

- liturgiczna - sprawowanie sakramentów i troska o uzewnętrznianie się chwały Bożej (dorobek kulturowy Kościoła, budownictwo

T. Pikus, Program ekumeniczny Jana Pawła II w encyklice „Ut unum sint”, [w:] S. Pawłowski (red.), Różnić się w zgodzie, Lublin 2008, s. 133. 
sakralne, śpiew, ryty i nabożeństwa); poprzez tę funkcję Kościół przyczynia się do budowy kultury ogólnoludzkiej;

- hodegetyczna - wyrażająca się w trosce o prawidłowe zarządzanie

i dyscyplinę oraz poprzez dobroczynność chrześcijańską ${ }^{4}$.

Jak wiara bez uczynków jest martwa, tak nie można mówić o autentycznym ekumenizmie bez wspólnego działania. Dlatego Dekret o ekumenizmie Unitatis redintegratio podkreśla współpracę nie tylko chrześcijan, ale „wszystkich ludzi” ${ }^{5}$ na wielu płaszczyznach. Dzięki tej współpracy „wszyscy wierzący w Chrystusa łatwo mogą się nauczyć, jak można nawzajem lepiej się poznać i wyżej ocenić oraz utorować drogę do jedności chrześcijan"6.

Szczególną uwagę zwróciły na siebie Kościoły i Wspólnoty chrześcijańskie w Polsce w czasie stanu wojennego (13.12.1981 - 22.07.1983). Wzajemnie współpracowały ośrodki charytatywne wszystkich wyznań chrześcijańskich, a okazywana wzajemna pomoc była realizacją przykazania miłości. W tym okresie nie ważne było, czy ktoś jest takiego czy innego wyznania, ważny był każdy człowiek.

\section{Wielowyznaniowość na Śląsku Cieszyńskim}

Ekumenizm końca XX wieku i początku trzeciego tysiąclecia to ruch nastawiony na przywrócenie jedności wśród uczniów Chrystusa. Jego istotą jest dążenie do jak najściślejszej współpracy Kościołów na wszystkich szczeblach życia kościelnego, a także poszukiwanie wspólnych elementów w poszczególnych wyznaniach, co jest realizowane szczególnie na Śląsku Cieszyńskim. Warto przywołać dane statystyczne obrazujące wyznaniowość na Śląsku Cieszyńskim, jak wyglądała ona na początku XX stulecia, a jak przedstawiała się na początku trzeciego tysiąclecia.

Na początku XX stulecia teren Księstwa Cieszyńskiego zamieszkiwało 385795 mieszkańców, w tym: 288906 (74,89\%) katolików, 86864 (22,51\%) protestantów, 9983 (2,59\%) Żydów i 42 (0,01\%) innego wyznania ${ }^{7}$. Po podziale Śląska Cieszyńskiego 28 lipca 1920, po stronie polskiej pozostał obszar $1200 \mathrm{~km}^{2}$ zamieszkały przez 169,6 tys. mieszkańców, a po stronie czechosłowackiej najbardziej uprzemysłowiona część regionu obejmująca powierzchnię $1281 \mathrm{~km}^{2}$ zamieszkiwana przez 295,2

Ibidem, s. 58-59.

5 Por. Sobór Watykański II, Dekret o ekumenizmie Unitatis redintegratio (dalej: DE) 12.

6 Ibidem.

7 J. Bilczewski, O Kościele Chrystusowym, Cieszyn 1908, s. 109. 
Teologia dialogu

tys. mieszkańców. Stąd po stronie polskiej było: katolików - 103200 , protestantów - 60 tys., Żydów - 5400 i 1 tys. wiernych innego wyznania. Na początku trzeciego tysiąclecia na Śląsku Cieszyńskim, po polskiej stronie 87\% mieszkańców to wyznawcy Kościoła rzymskokatolickiego, $11 \%$ Kościoła ewangelicko-augsburskiego. Pozostałe $2 \%$ to wolni chrześcijanie, metodyści, baptyści, adwentyści dnia siódmego oraz wyznawcy innych wspólnot chrześcijańskich i religii ${ }^{8}$.

25 marca 1992 roku bullą Jana Pawła II Totus Tuus Poloniae Populus została ustanowiona diecezja bielsko-żywiecka, w skład której wszedł Śląsk Cieszyński. Zajmuje ona obszar ok. 3 tys. $\mathrm{km}^{2}$ i jest podzielona na 23 dekanaty i 207 parafii. Diecezja liczy 798 tys. mieszkańców, w tym 698 tys. wiernych katolików9 ${ }^{9}$

Podczas kanonicznego objęcia urzędu biskupa diecezji bielsko-żywieckiej i rozpoczęcia posługi pasterskiej, w dniu 9 maja 1992 roku, ks. bp Tadeusz Rakoczy, wyrażając wdzięczność za udział w tej uroczystości przedstawicieli Kościoła ewangelicko-augsburskiego, ofiarował im „szczerą i braterską współpracę ekumeniczną na tym terenie w duchu II Soboru Watykańskiego”. Po czym biskup wyraził życzenie: „Oby łaska Boga Wszechmogącego wspierała nasze wysiłki w budowaniu jedności"10. Tak więc ekumenizm znalazł się w programie działania nowo mianowanego biskupa diecezjalnego, który program ten nazwał „hermeneutyką serca”"11. Było to nawiązanie do ustaleń Soboru

$\mathrm{Na}$ początku trzeciego tysiąclecia w granicach diecezji działają 22 Kościoły i Wspólnoty chrześcijańskie: Kościół ewangelicko-augsburski (ok. 50 tys. wyznawców), Kościół polskokatolicki (360), Kościół prawosławny (70), Kościół greckokatolicki (120), Kościół ewangelicko-reformowany (15), Kościół Chrześcijan Baptystów (80), Kościół ewangelicko-metodystyczny (70), Kościół Adwentystów Dnia Siódmego (1100), Kościół Wolnych Chrześcijan (820), Kościół Chrześcijan Dnia Sobotniego (90), Związek Badaczy Biblii w RP (30), Zbory Boże Chrześcijan Dnia Siódmego (50), Misja „Centrum” Służby Zdrowia (60), Chrześcijańska Wspólnota Ewangeliczna (50), Zrzeszenie Wolnych Badaczy Pisma Świętego (350), Zbór Ewangeliczny „Syjon” w Dzięgielowie (60), Chrześcijańska Wspólnota Zielonoświątkowców (160), Zbór Stanowczych Chrześcijan w RP (310), Kościół Zielonoświątkowy (2000), Świecki Ruch „Epifania” (70), Kościół Ewangelicznych Chrześcijan (brak danych) oraz Ewangeliczny Zbór Braterski (20). W sumie teren diecezji zamieszkuje 55.115 chrześcijan (z wyjątkiem katolików). Por. J. Budniak, Ekumenizm na granicy, [w:] J. Kempa (red.), Kościót wobec granic, Katowice 2005, s. 115.

T. Borutka, Diecezja Bielsko-Żywiecka 1992-1997, Bielsko-Biała 1997, s. 7-8.

Stowo Księdza Biskupa Tadeusza Rakoczego podczas ingresu do katedry św. Mikołaja w Bielsku-Białej. „Kwartalnik Diecezjalny” (dalej: KD) - Pismo Urzędowe Diecezji Bielsko-Żywieckiej 1992, nr 1, s. 26.

Ibidem, s. 27. 
Watykańskiego II, który wypracował pojęcie „hierarchia prawd”12 i uznał je za zasadę hermeneutyczną dla interpretacji dogmatów wiary przyjętych w Kościele rzymskokatolickim. Może ona również odegrać istotną rolę w odbudowywaniu komunii między Kościołami i wspólnotami chrześcijańskimi.

Ekumenizm na Śląsku Cieszyńskim, jak i w całej diecezji bielsko-żywieckiej praktykowany jest na trzech płaszczyznach: ekumenizmu duchowego, naukowego i praktycznego. Ma swoją specyfikę wynikającą z uwarunkowań historycznych. Ma też swoją tradycję, gdyż modlitwa o jedność chrześcijan praktykowana była tu już w latach 70 . XX wieku, czyli zaraz po II Soborze Watykańskim, który wydając Dekret o ekumenizmie Unitatis redintegratio wprowadził Kościół katolicki w ruch ekumeniczny.

Dnia 22 maja 1995 roku wierni Kościoła lokalnego przeżyli wizytę apostolską Jana Pawła II do diecezji bielsko-żywieckiej z okazji kanonizacji św. Jana Sarkandra. W związku z tym biskup ordynariusz Tadeusz Rakoczy wydał dokument powołujący Diecezjalny Komitet Pielgrzymki Ojca Świętego Jana Pawła II do Diecezji Bielsko-Żywieckiej. W skład tego Komitetu wszedł duszpasterz odpowiedzialny za kontakty ekumeniczne. Jego zadaniem było m. in. koordynowanie współpracy z Kościołem ewangelickim, a szczególnie w przygotowaniu ekumenicznego spotkania ewangelików ze Śląska Cieszyńskiego z papieżem Janem Pawłem II w kościele luterańskim w Skoczowie ${ }^{13}$.

Przygotowując się do przyjęcia Papieża w diecezji, bp T. Rakoczy wydał List pasterski, w którym nawiązał do głównego powodu przybycia Ojca Świętego do Skoczowa - kanonizacji św. Jana Sarkandra - oraz zwrócił uwagę na to, że niektórzy ewangelicy zamieszkujący Ziemię Cieszyńską zachowują pewną powściągliwość, a nawet rezerwę wobec tego faktu. Biskup pragnie kontrowersje, co do postaci Sarkandra, rozwiązać na drodze historycznej, argumentując tym, że kanonizacja jest m.in. rozrachunkiem ze złem i nienawiścią, bez względu na to od kogo i skąd pochodzi. Biskup Rakoczy uważał, że spotkanie Papieża ze wspólnotą ewangelicką w Kościele luterańskim pw. Trójcy Świętej w Skoczowie winno stać się ,kamieniem milowym na naszych beskidzkich drogach ekumenicznych, którymi od lat odważnie kroczymy" ${ }^{14}$. Słowa bp. T. Rakoczego

\footnotetext{
$12 \quad$ DE 11.

13 Zob. KD 1995, nr 2, s. 190-201.

$14 \quad$ Ibidem, s. 207-213.
} 
Teologia dialogu współbrzmią ze słowami Jana Pawła II, które wypowiedział podczas Mszy św. kanonizacyjnej 21 maja 1995 roku w Ołomuńcu:

Kanonizacja ta nie chce w żadnym wypadku otwierać bolesnych ran, które w przeszłości na tych ziemiach naznaczyły Ciało Chrystusowe; zamiarem jej jest, bowiem powierzyć jedność chrześcijan opiece sławnego męczennika. Dzisiaj, ja, papież Kościoła rzymskiego, w imieniu wszystkich katolików proszę o wybaczenie krzywd, popełnionych na niekatolikach w burzliwych dziejach tego narodu; jednocześnie zapewniam, że Kościół katolicki wybacza to wszystko zło, które wycierpiały z kolei jego dzieci. Niech dzień dzisiejszy będzie nowym początkiem we wspólnych staraniach naśladowania Chrystusa, Jego Ewangelii, Jego prawa miłości, Jego największej tęsknoty za jednością wierzących w Chrystusa: „Aby wszyscy byli jedno” ${ }^{15}$.

Dzień 22 maja 1995 roku można uznać za największe wydarzenie ekumeniczne w młodej historii diecezji bielsko-żywieckiej. Podczas modlitwy ekumenicznej w Kościele ewangelicko-augsburskim pod wezwaniem Świętej Trójcy w Skoczowie Jan Paweł II podkreślił znaczenie dialogu ekumenicznego dla diecezji bielsko-żywieckiej stwierdzając, że

[...], ziemia bielska i Śląsk Cieszyński jest znana w Polsce, jako miejsce szczególnego świadectwa ekumenicznego. Jest on od dawna terenem harmonijnego współżycia wiernych Kościoła katolickiego i Kościoła ewangelicko-augsburskiego oraz intensywnego dialogu ekumenicznego. Prowadzi się go tutaj z głębokim przekonaniem, iż tak wiele nas łączy, iż łączy na wspólna wiara w Chrystusa i wspólna Ojczyzna ${ }^{16}$.

Słowa te wskazują na rolę oraz znaczenie, jakie pełnił i pełni dialog ekumeniczny. Papież swoje wystąpienie zakończył słowami:

[...], pragnę wyrazić moje osobiste zadowolenie i wdzięczność, że ten dialog ekumeniczny rozwija się i pogłębia, oraz że znajduje wyraz także w rozmaitych formach konkretnej współpracy, tak na płaszczyźnie diecezjalnej jak i w poszczególnych parafiach ${ }^{17}$.

Wszystkim działaniom chrześcijan, również w diecezji bielsko-żywieckiej, powinien towarzyszyć dialog, który jest podstawą współczesnego ruchu ekumenicznego, a który wydaje się coraz śmielej

$15 \quad$ Homilia Ojca Świętego Jana Pawta II wygtoszona podczas kanonizacji św. Jana Sarkandra w Ołomuńcu-21 maja 1995 roku. Por. Celebratines liturgicae.Quibus praeest Summus Pontifex Johannes Paulus PP II, Olomouc 21 maii 1995.

16 Jan Paweł II, Przemówienie wygtoszone $w$ czasie spotkania $z$ wiernymi $w$ kościele ewangelicko- augsburskim w Skoczowie, [w:] Drogowskazy dla Polaków Ojca Świętego Jana Pawta II, Kraków 1999, t. 3, s. 273.

17 Ibidem, s. 116. 
przekraczać rozmaite bariery religijne, społeczne, kulturowe, etniczne, a nawet polityczne ${ }^{18}$.

\section{Duchowe i pastoralne inicjatywy ekumeniczne}

Biskupi bielsko-żywieccy, wypełniając zalecenia Dekretu o ekumenizmie Unitatis redintegratio II Soboru Watykańskiego, powierzyli troskę o koordynowanie działań na rzecz jedności chrześcijan na terenie diecezji referentowi ekumenicznemu.

Realizując wytyczne zawarte w Dyrektorium Ekumenicznym w numerze $41^{19}$ biskup bielsko-żywiecki Tadeusz Rakoczy w czerwcu 1992 roku mianował ks. Józefa Budniaka referentem do spraw ekumenizmu w diecezji bielsko-żywieckiej ${ }^{20}$. W akcie nominacyjnym biskup wskazał na zadania, jakie ma realizować referent: wprowadzać w życie decyzje Soboru Watykańskiego II w sprawie ekumenizmu,

popierać ekumenizm duchowy, poprzez publiczne i prywatne modlitwy o zjednoczenie chrześcijan, prowadzić działalność naukową organizując konferencje ekumeniczne, rozwijać wzajemną życzliwość i przyjaźń oraz umacniać miłość między katolikami a chrześcijanami innych wyznań. Wreszcie starać się o wznowienie dialogu z braćmi odłączonymi i udzielać pomocy w kształceniu i wychowaniu duchownych i świeckich do życia w duchu ekumenizmu ${ }^{21}$.

Przekazując nominację referentowi ds. ekumenizmu biskup zwrócił się do niego słowami: „Badania teologiczno-historyczne, kompetencja i osiągnięcia w działalności ekumenicznej Księdza Profesora spotykają się tak z moim, jak i powszechnym uznaniem"22.

Rok liturgiczny najlepiej ilustruje działalność zjednoczeniową na Śląsku Cieszyńskim Adwent, to czas kiedy chrześcijanie razem przygotowują się na Boże Narodzenie. Okres Adwentu nazwany jest również czasem oczekiwania. Tak samo ekumenizm jest czasem oczekiwania na dzień, kiedy chrześcijanie będą razem. Stąd abp Alfons Nossol wyszedł z inicjatywą, aby w pierwszą Niedzielę Adwentu 1997 roku w katedrze opolskiej spotkała się młodzież na modlitwie ekumenicznej.

18 J.Budniak, Wtrzecie tysiaclecieku,,petnejkomunii”, [w:] J. Budniak, M. J. Uglorz (red.), Z Duchem Świętym w trzecie tysiaclecie, Cieszyn 2001, s. 229-236.

Dyrektorium $w$ sprawie realizacji zasad $i$ norm dotyczacych ekumenizmu (25.03.1993), „Communio” 1994, 2 (80), nr 41.

Akty personalne ks. Józefa Budniaka, [w:] Archiwum Kurii Diecezjalnej w Bielsku-Białej (1992).

21 Ibidem.

22 W archiwum prywatnym autora. Sygn.: JB/VI.1992/Ek. 
Arcybiskup motywując swe zaproszenie powiedział: „chcemy tam dialogu wspólnie - wszyscy chrześcijanie, w ramach ekumenicznego nabożeństwa, złączyć się w przyzywaniu mocy Bożego Ducha i wypraszaniu daru jedności dla zewnętrznie podzielonego jeszcze Kościoła"23. Słowa zaproszenia skierował także pod adresem wszystkich duszpasterzy: „również Was, drodzy Duszpasterze, proszę o włączenie się w ekumeniczną modlitwę Kościoła. Niech stanie się ona, momentem przeobrażenia naszych serc i sprawi, byśmy byli bliżej siebie, a tym samym bliżej Chrystusa"24. Odtąd, co roku Ekumeniczna Modlitwa Młodych rozpoczyna nowy rok liturgiczny, na którym są obecni duszpasterze i młodzież różnych Kościołów i wspólnot chrześcijańskich, zwłaszcza katolicy i ewangelicy. Na wzór spotkań opolskich również na Śląsku Cieszyńskim odbywa się na początku nowego roku liturgicznego Ekumeniczna Modlitwa Młodych.

Okres Bożego Narodzenia, to także czas wspólnego przeżywania tajemnicy Wcielenia. Tym razem odwołajmy się do przykładu z Brennej na Śląsku Cieszyńskim, gdzie od 1990 roku, corocznie, na Pasterce w kościele parafialnym pw. św. Jana Chrzciciela proboszcz parafii ewangelickiej wygłasza uroczyste kazanie, a w uroczystość Bożego Narodzenia proboszcz parafii katolickiej zwiastuje Słowo Boże w kościele luterańskim. Cały okres Narodzenia Pańskiego na Śląsku Cieszyńskim to wspólne kolędowanie z udziałem chórów katolickich i ewangelickich.

Po zakończeniu okresu Bożego Narodzenia Kościół przeżywa w dniach od 18 do 25 stycznia Tydzień Modlitwy o Jedność Chrześcijan. Jan Paweł II w encyklice Ut unum sint poucza, że ekumeniczna modlitwa służy chrześcijańskiemu posłannictwu i jego wiarygodności; co więcej, warunkuje nowe widzenie Kościoła i chrześcijaństwa ${ }^{25}$. Tradycja Tygodnia Modlitw o Jedność Chrześcijan obchodzonego w styczniowych dniach na terenie całej Polski jest szczególnie mocno zakorzeniona na Śląsku Cieszyńskim. Tydzień Modlitw wydłuża się w prawie miesięczne modlitewne czuwanie uczniów Jezusa w intencji jedności.

W styczniu 1993 roku, w związku z Tygodniem Powszechnej Modlitwy o Jedność Chrześcijan, ks. bp T. Rakoczy skierował do diecezjan List pasterski zatytułowany Przynosić owoc Ducha dla jedności

${ }_{23} \quad$ Z. Glaeser, Ekumeniczne przyzywanie Ducha Świętego. Refleksje na marginesie ekumenicznych spotkań chrześcijan $w$ diecezji opolskiej, „Biuletyn Ekumeniczny” 1999, nr 2, s. 41.

24 Ibidem, s. 41.

25 Jan Paweł II, encyklika Ut unum sint (dalej: UUS) 23. 
chrześcijan. W słowie pasterskim podkreślił wspólną odpowiedzialność chrześcijan żyjących na terenie diecezji, którzy powinni stanowić jedną rodzinę, bowiem ,zjednoczenie Kościołów jest pierwszorzędTeologia dialogu nym i skutecznym znakiem pojednania między ludźmi i między narodami, a dzisiejszy świat jest stałym wezwaniem skierowanym do rozdzielonych chrześcijan, aby modlili się i działali na rzecz jedności". W zakończeniu Listu Biskup zaprosił diecezjan do modlitwy o Jedność, o to, ,aby Duch Święty wspierał swą mocą nasze Kościoły i dopomógł nam, otworzyć nasze serca na tchnienie Jego życiodajnej łaski"26. Działania ekumeniczne stanowią ważny element posługi ks. biskupa, gdyż „biskup ma pierwszeństwo w ofiarnej miłości do wiernych i do Kościoła"27.

Z udziałem biskupów, T. Rakoczego i P. Anweilera, odbywa się co roku, w ramach Tygodnia Modlitw o Jedność Chrześcijan, w Książnicy Beskidzkiej w Bielsku-Białej maraton biblijny, podczas którego poszczególne fragmenty Pisma Świętego są czytane przez zaproszonych gości różnych wyznań. Maraton ten jest bezpośrednio transmitowany przez radio diecezjalne, „Anioł Beskidów”.

Pod koniec XX stulecia w czterech diecezjach polskich: warszawskiej, warmińskiej, mazurskiej i bielsko-żywieckiej obchodzone są Światowe Dni Modlitwy Kobiet. Światowy Dzień Modlitw jest wspólną akcją kobiet wielu wyznań, docierającą do 170 krajów. Co roku w innym kraju odbywają się centralne uroczystości Światowego Dnia Modlitw Kobiet. Po raz pierwszy takie modlitwy odbyły się w Polsce w roku 2005, a centralne nabożeństwo odbyło się w Kościele ewangelicko-augsburskim w Cieszynie. Poza centralnym nabożeństwem w każdym kraju, w pierwszy piątek miesiąca marca, odbywają się ekumeniczne nabożeństwa kobiet. W skład komitetu odpowiedzialnego w Polsce za przygotowanie i napisanie liturgii modlitewnego nabożeństwa weszły reprezentantki sześciu Kościołów członkowskich Polskiej Rady Ekumenicznej oraz Kościoła rzymskokatolickiego i greckokatolickiego.

Wielki Post kojarzy się przede wszystkim z nabożeństwami pasyjnymi. Katolicy uczestniczą w Drodze Krzyżowej, Gorzkich Żalach i w rozważaniu kazania pasyjnego, a ewangelicy w swoich świątyniach w rozważaniu tajemnicy męki, cierpienia i śmierci Pana Jezusa.

Na Śląsku Cieszyńskim ekumeniczne nabożeństwa pasyjne celebrowane były od 1996 roku w Bielsku-Białej, na przemian - w jednym

26 T. Rakoczy, List do wiernych w zwiazku z Tygodniem Ekumenicznym, KD 1993, nr 1-2, s. 23.

27 Jan Paweł II, Wstańcie, chodźmy. Cz.1. Powołanie, „L'Osservatore Romano” wydanie polskie (dalej: L'OssRom (PL)) $2004 \mathrm{nr}$ 7-8 (265) s. 21. 
roku w katedrze bielskiej, a w następnym - w Kościele ewangelickim Zbawiciela. Misterium pasyjne w katedrze katolickiej przybiera postać Drogi Krzyżowej, w trakcie której rozważania pasyjne wygłasza biskup ewangelicki. W Kościele luterańskim podczas nabożeństwa pasyjnego kazanie wygłasza biskup katolicki.

Od 1990 roku liturgia Wielkiej Soboty połączona z uroczystą rezurekcją Zmartwychwstania Pańskiego przybrała w parafii pw. św. Jana Chrzciciela w Brennej charakter ekumeniczny - biorą w niej udział: proboszcz parafii ewangelickiej w tej miejscowości oraz rodziny katolicko-ewangelickie. Ksiądz luterański podczas rezurekcji w Wielką Sobotę zwiastuje Słowo Boże dotyczące tajemnicy Zmartwychwstania Pańskiego. W Niedzielę Zmartwychwstania Pańskiego z kolei proboszcz katolicki wygłasza kazanie na nabożeństwie świątecznym w Kościele ewangelickim.

W roku liturgicznym poza Adwentem i Wielkanocą organizowane są jeszcze inne spotkania ekumeniczne. Zainteresowana ruchem na rzecz zjednoczenia jest młodziė̇, która włącza się w różne inicjatywy zjednoczeniowe, takie jak: wspólna modlitwa ekumeniczna, udział w grupach Taizé, Ruchu Focolari i innych wspólnotach ekumenicznych, podejmowanie wspólnych działań kulturalnych i charytatywnych. Jedno z pierwszych nabożeństw ekumenicznych w Polsce z udziałem młodzieży odbyło z inicjatywy bp. Herberta Bednorza, ordynariusza diecezji katowickiej, w lutym 1980 roku w Cieszynie, w kościele pw. Wniebowzięcia Najświętszej Maryi Panny (OO. Bonifratrzy). Młodzież katolicka i ewangelicka modliła się wraz z Biskupem o jedność chrześcijan. Biskup Bednorz w swoim wystąpieniu zachęcił młodych ludzi do dawania wspólnego świadectwa o Jezusie Chrystusie. „Wy jesteście nie tylko nadzieją Kościoła, ale także nadzieją przyszłej jedności”"28.

Wspólna modlitwa o pokój, który jest darem miłości Bożej, musi się opierać na czterech filarach: na prawdzie, sprawiedliwości, miłości i wolności. Towarzyszy ona duszpasterzom i wiernym diecezji, wszak

prawdziwy pokój rozkwita, bowiem wtedy, kiedy serce przezwycięża nienawiść, urazę i zazdrość, kiedy mówi się «nie» egoizmowi i wszystkiemu, co skłania istotę ludzką do skoncentrowania się na sobie i do obrony własnych interesów ${ }^{29}$.

To właśnie nabożeństwa ekumeniczne o pokój - nawiązujące do międzyreligijnego spotkania modlitewnego o pokój, zorganizowanego po raz pierwszy w 1986 roku z inicjatywy papieża Jana Pawła II w Asyżu

28 W archiwum prywatnym autora. Sygn. JB/1980/00B.

$29 \quad$ Jan Paweł II, Jak budować pokój? (Przemówienie wygłoszone 14 kwietnia 2003 roku do uczestników Kongresu UNIV), L'OssRom (PL) 2003, 6 (254) s. 32. 
są kolejnym przykładem potwierdzającym powyższe inicjatywy zjednoczeniowe. Pierwsze nabożeństwo o wymiarze międzynarodowym z udziałem duchownych z Polski i z Republiki Czeskiej odbyło się 18 marca 2002 roku w kościele pw. św. Jana Chrzciciela w Brennej. Wspólnej modlitwie przedstawicieli pięciu Kościołów chrześcijańskich (rzymskokatolicki, ewangelicko-augsburski, polskokatolicki, prawosławny, starokatolicki mariawitów) przewodniczył biskup diecezji bielsko-żywieckiej Tadeusz Rakoczy, a kazanie wygłosił ks. Tadeusz Szurman, biskup diecezji katowickiej Kościoła ewangelicko-augsburskiego ${ }^{30}$. Episkopat Republiki Czeskiej reprezentował biskup ostrawsko-opawski Franciszek Lobkowicz, a Czeską Radę Ekumeniczną - bp Władysław Wolny z Kościoła ewangelicko-augsburskiego.

Doceniając rolę i znaczenie dialogu ekumenicznego na Śląsku Cieszyńskim z inspiracji Prezydenta Polski Bronisława Komorowskiego, w dniu 1 września 2011 roku, w Cieszynie odbyła się ekumeniczna modlitwa o pokój na świecie. Wzięli w niej udział biskupi katoliccy i luterańscy przy udziale wiernych obu wyznań. Nawiązując do położenia Cieszyna Prezydent Komorowski powiedział również, że głos z tego miejsca, z pogranicza narodów, języków, kultur i religii zaświadcza, że różnorodność nie jest źródłem nieszczęścia, lecz piękna i bogactwa Polski i wszystkich narodów świata.

Z okazji Światowego Dnia Biblii chrześcijanie różnych wyznań uczestniczą w miesiącu maju w spotkaniach i ekumenicznych modlitwach organizowanych na terenie całej Polski. Celem inicjatyw jest modlitwa o jedność i pokój oraz popularyzacja Biblii. Organizatorem Ekumenicznych Dni Biblii jest Towarzystwo Biblijne w Polsce. Posługa Ekumenicznych Dni Biblijnych dowodzi, jak ważne miejsce w ruchu ekumenicznym zajmuje Pismo Święte i jak wyraźnie ta forma ekumenizmu jest obecna w przestrzeni ,polskiej nadziei ekumenicznej”, jak określił to abp Alfons Nossol ${ }^{31}$. Światowe Dni Biblii są obchodzone we wszystkich diecezjach.

Od 1998 roku z okazji Światowego Dnia Biblii odbywają się w różnych miejscowościach diecezji, a szczególnie w części Śląska Cieszyńskiego, nabożeństwa ekumeniczne poprzedzane wykładami z zakresu teologii biblijnej. Obok katolików i ewangelików w spotkaniach tych uczestniczą przedstawiciele Kościoła prawosławnego, Kościoła 
polskokatolickiego i Adwentystów Dnia Siódmego ${ }^{32}$. Organizatorem dialogu tych spotkań jest Komitet Ekumenicznych Dni Biblijnych. Inicjatywa ta jest realizacją idei współpracy ekumenicznej ukierunkowanej na popularyzację Pisma Świętego (olimpiady biblijne przeprowadzane w szkołach) ${ }^{33}$.

Obok majowych Dni Biblijnych warto wspomnieć o szkolnym ekumenicznym konkursie biblijnym. Po raz pierwszy konkurs ten odbył się w roku szkolnym 1997/1998 i od tego czasu na stałe wszedł do programu edukacji ekumenicznej młodzieży w katolickiej diecezji bielsko-żywieckiej i ewangelickiej diecezji cieszyńskiej. Inicjatorem konkursu jest zarząd ewangelickiego Towarzystwa Katechetycznego „Jonasz” ze Skoczowa, a nad jego przebiegiem czuwają wizytatorzy katechetyczni - katolicki i ewangelicki. Konkurs ten został włączony do listy olimpiad przedmiotowych, organizowanych pod patronatem Kuratorium Oświaty i Wychowania w Bielsku-Białej.

W pierwszej edycji konkursu wzięło udział 12 tys. uczniów szkół województwa bielskiego, a do ścisłego finału weszło ponad 80 uczniów ze szkół podstawowych i 43 ze szkół średnich ${ }^{34}$. Co roku konkurs kończy się w maju, a uroczystość ta zawsze ma charakter ekumeniczny - uczestniczą w niej przedstawiciele władz Kościołów katolickiego i ewangelickiego, którzy wręczają laureatom nagrody i dyplomy.

Konkurs biblijny spełnia nie tylko funkcję poznawczą, w której dzieci i młodzież szkolna poznają Pismo Święte pogłębiając swoją wiedzę religijną i wiarę, ale także pełni ważną funkcję integracyjno-ekumeniczną i przyczynia się do ukształtowania u dzieci i młodzieży postawy szacunku wobec Pisma Świętego.

Kolejnym priorytetem działalności ekumenicznej, a zarazem fundamentem działalności praktycznej, są małżeństwa osób o różnej przynależności wyznaniowej (popularnie zwane małżeństwami mieszanymi) i objęcie ich przez Kościoły opieką duszpasterską. Istotne w duszpasterstwie ekumenicznym rodzin są następujące zasady: zachęcanie wiernych do modlitwy o jedność chrześcijan i udziału we wspólnych nabożeństwach i innych formach działalności parafii, wzbogacanie wiedzy o Kościołach, przypomnienie rodzicom, że dziecko mimo przynależności do jednego z Kościołów powinno być edukowane o duchowym bogactwie drugiego Kościoła przez udział

32 J. Budniak, Ekumenizm na Ślasku Cieszyńskim na przełomie wieków, [w:] Pojednajcie się ..., s. 74.

33 Idem, Ekumenizmjutra na przykładzie Ślaska Cieszyńskiego Studium historyczno-pastoralne, Katowice 2002, s. 119.

34 www.diecezja.bielsko.pl/archiwum/wydarzylo/Konk_bib.htm (16.10.1998). 
w uroczystościach, nabożeństwach lub wspólne jego nawiedzanie. Na Śląsku Cieszyńskim są parafie, gdzie duszpasterze katolicki i ewangelicki, wspólnie odwiedzają rodziny wielowyznaniowe. Wspólnie się modlą, a następnie podejmują z rodziną rozmowę na różne tematy. Tak rozumiane duszpasterstwo ekumeniczne, które w rzeczywistości jest formą dialogu wiary w rodzinie, może służyć umocnieniu miłości małżonków, będącej zarazem przykładem miłości ekumenicznej i znakiem jedności dla podzielonego Kościoła. Dobrze prowadzone duszpasterstwo małżeństw osób o różnej przynależności wyznaniowej może doprowadzić do tego, że te małżeństwa staną się wzorem, modelem działalności ekumenicznej. Odwiedziny duszpasterskie małżeństw mieszanych można uznać za ważny element opieki duszpasterskiej nad zawartymi już małżeństwami mieszanymi i ich rodzinami, której zasady określają również przepisy prawa kanonicznego. W Kodeksie Prawa Kanonicznego czytamy:

Ordynariusze miejsca oraz inni duszpasterze winni troszczyć się o to, ażeby katolickiemu małżonkowi i dzieciom zrodzonym z małżeństwa mieszanego nie zabrakło pomocy duchowej do wypełnienia ich obowiązków. Mają też wspierać małżonków w utrwaleniu jedności życia małżeńskiego i rodzinnego ${ }^{35}$.

Dla przybliżenia tej specyficznej formy opieki duszpasterskiej nad małżeństwami mieszanym odwołajmy się do przykładu z Brennej, gdzie często duchowni katolicki i ewangelicki razem odwiedzają te rodziny. Najczęściej odwiedziny te są w okresie Bożego Narodzenia i polegają na wspólnej ze wszystkimi członkami rodziny modlitwie, śpiewaniu kolęd, wspólnych przecież dla obu Kościołów, rozmowach i udzieleniu im przez obu księży błogosławieństwa.

Odwiedziny duszpasterskie - kolęda - na Śląsku Cieszyńskim są niejednokrotnie okazją do zapoznania się z rodzinami mieszanymi wyznaniowo, gdzie często spotyka się takie małżeństwa, które miały ślub w Kościele ewangelickim bez dyspensy od formy kanonicznej. Jak pokazuje kilkuletnie doświadczenie, odwiedziny duszpasterskie małżeństw mieszanych wyznaniowo przyjmowane są przez ich członków z wielką życzliwością. Są okazją do rozwiązania wielu dylematów życiowych w takich rodzinach, związanych przede wszystkim z praktykami religijnymi, konfliktami rodzinnymi na tle różnicy wyznania i wychowania dzieci. Duszpasterze często występują w roli rozjemców i doradców, realizując jednocześnie podstawowe zasady ruchu ekumenicznego.

Pogrzeby ekumeniczne ściśle wiążą się z duszpasterstwem małżeństw i rodzin wielowyznaniowych, bowiem najczęściej taki charakter 
mają pogrzeby członków ich rodzin. Jednakże prawie każdy pogrzeb na Śląsku Cieszyński ma zabarwienie ekumeniczne - prawie zawsze biorą w nim udział osoby różnych wyznań, co wynika z charakteru życia codziennego w tym regionie. Zdarza się, że w pogrzebie katolika z małżeństwa mieszanego uczestniczy ksiądz ewangelicki i odwrotnie - w pogrzebie strony ewangelickiej uczestniczy ksiądz katolicki. Kiedy duchowny ewangelicki bierze udział w liturgii pogrzebowej w kościele katolickim, to czyta fragment z Biblii i głosi kazanie. Z kolei ksiądz katolicki, kiedy uczestniczy w nabożeństwie pogrzebowym w kościele ewangelickim, to odczytuje słowa z Pisma Świętego i głosi egzortę pogrzebową.

W tradycji Śląska Cieszyńskiego zaistniał również fakt bicia dzwonów kościelnych. Gdy kondukt pogrzebowy przechodzi koło Kościoła ewangelickiego, a jest to pogrzeb katolicki, biją dzwony z wieży tego kościoła i odwrotnie, gdy jest pogrzeb ewangelicki, to biją dzwony z Kościoła katolickiego.

Tydzień Ewangelizacyjny w Dzięgielowie to ważne i wielkie wydarzenie religijne w Europie Wschodniej organizowane przez Kościół ewangelicko-augsburski. Na program całotygodniowej formy ewangelizacyjnej składają się nabożeństwa, cykle wykładów, ewangelizacja, koncerty. Całość spotkania ma charakter ekumeniczny, czego dowodem jest, oprócz ewangelików i katolików, obecność innych chrześcijan należących do innych Kościołów i wspólnot eklezjalnych. Tydzień Ewangelizacyjny to kolejny dowód na to, że świadomość ekumeniczna staje się coraz większa, a ekumenizm zbliża do siebie ludzi, w tym i najmłodsze pokolenie.

Coraz częściej obserwujemy w regionach zróżnicowanych wyznaniowo przypadki wzajemnego użyczania świątyń i kaplic cmentarnych przez różne Kościoły i Wspólnoty. Przykładem wrażliwości ekumenicznej jest użyczenie kościoła ewangelickiego katolikom w Międzyrzeczu k/Bielska-Białej. W nocy z 25/26 stycznia 1993 roku spłonął tam XVI-wieczny drewniany kościół katolicki pw. św. Marcina. Już tydzień po pożarze w ewangelickim kościele odprawiono pierwszą Mszę św. W murach tej świątyni przez siedem lat, aż do wybudowania nowego kościoła celebrowane były Msze św. w każdą niedzielę, w święta i uroczystości, śluby i pogrzeby, Pierwsze Komunie św. oraz bierzmowania.

Interesującą formą ruchu ekumenicznego na Śląsku Cieszyńskim są ekumeniczne nabożeństwa strażaków gromadzące od 1999 roku przedstawicieli strażaków państwowej i ochotniczej straży pożarnej województwa śląskiego. Podczas ekumenicznego nabożeństwa 
strażaków w dniu 3 lutego 2000 roku w Goleszowie na Śląsku Cieszyńskim, prezes OSP Leszek Szlauer, powiedział m.in.:

strażacy są wzorem najprawdziwszej ekumenii, bo gdy pali się komuś dom, nie pytam, czy jest moim współwyznawcą, czy katolikiem. Nie robimy żadnych podziałów wyznaniowych. Podczas akcji musimy darzyć się pełnym zaufaniem, a w niedzielę każdy idzie do swego kościoła ${ }^{36}$.

Doniosłym wydarzeniem ekumenicznym było poświęcenie ekumenicznej kaplicy uniwersyteckiej w Filii Uniwersytetu Śląskiego w Cieszynie, w dniu 12 maja 1998 roku $^{37}$. Otwarcie tej kaplicy to kolejny fakt, który zapisał się w tradycji uniwersyteckiej, w historii Cieszyna, Polski i Kościoła. W kaplicy odbywają się nabożeństwa ekumeniczne, 2 razy w tygodniu sprawowana jest Msza św., na początku roku akademickiego organizowane są rekolekcje dla studentów, a w każdym semestrze prowadzony jest kurs Alfa. Obecność kaplicy ekumenicznej w budynku uniwersyteckim ma również na celu przezwyciężanie barier wyznaniowych.

Ekumeniczne nabożeństwa towarzyszą społecznościom lokalnym podczas obchodów świąt kościelnych i państwowych (3 maja, 15 sierpnia i 11 listopada).

W roku 2008 roku parafia Kościoła ewangelicko-augsburskiego w Cieszynie przeżywała 300 -setną rocznicę powstania. Z tej okazji w dniu 5 października w kościele Jezusowym odbyło się uroczyste nabożeństwo ekumeniczne inaugurujące obchody jubileuszowe z udziałem wiernych i duchowieństwa Kościoła katolickiego na czele z bp. Tadeuszem Rakoczym oraz przedstawicieli wszystkich Kościołów i wspólnot chrześcijańskich Śląska Cieszyńskiego. W uroczystości wziął udział Prezydent Rzeczypospolitej Polskiej, Lech Kaczyński oraz Przewodniczący Parlamentu Europejskiego, Jerzy Buzek.

Od czerwca 1995 roku do chwili obecnej, w odpowiedzi na Encyklikę Ut unum sint, w katedrze św. Mikołaja w Bielsku Białej, co miesiąc, w każdy drugi czwartek miesiąca, odprawiana jest Msza św. w intencji jedności wszystkich chrześcijan, po której, dla członków Klubu Inteligencji Katolickiej, odbywa się spotkanie formacyjne dotyczące tematyki ekumenicznej ${ }^{38}$. Między innymi w ten sposób propagowane

36 M. Legendź, Ustyszałem alarm i pobiegłem, „Zwiastun” 2000, nr 4, s. 9.

37 J. Budniak, Kaplica ekumeniczna $w$ filii Uniwersytetu Ślaskiego $w$ Cieszynie. Powrót do tradycji. „Śląskie Studia Historyczno-Teologiczne” 1998, nr XXXI, s. 391.

38 Por.Trwać razem we wspólnocie. Ekumeniczne spotkania modlitewne wkatedrze św. Mikołaja w Bielsku-Białej w latach 1984-2012, oprac. B. Mebel, Z. Gebauer, Bielsko-Biała 2012, s. 24. 
są wśród wiernych idee ekumenizmu, gdyż sprawa jedności dotyczy wszystkich chrześcijan nie tylko tych, którzy bezpośrednio zaangażowani są w działalność ekumeniczną i podejmują odpowiednie inicjatywy na jego rzecz, ale i tych, którzy wspierają dialog ekumeniczny modlitwą i swoją postawą duchową.

Ekumeniczne poświęcenie obiektów sportowych i szkół to kolejny przykład bycia razem katolików i ewangelików, a rozpoczęło się to dopiero w 1989 roku, od „Okrągłego stołu”. Kościoły rozpoczęły intensywną działalność ekumeniczną nie tylko na płaszczyźnie kultury, ale także spędzania wolnego czasu, w tym rekreacji i sportu.

Charakter ekumeniczny posiadają inauguracje nowego roku szkolnego i akademickiego. Na inauguracje zapraszani są duchowni różnych wyznań chrześcijańskich, a niekiedy są one połączone z nabożeństwem ekumenicznym. Godne podkreślenia są nabożeństwa ekumeniczne z okazji inauguracji i zakończenia roku szkolnego zarówno w przedszkolach, jak i w szkole podstawowej i gimnazjum, jakie wprowadził w parafii w Pogwizdowie koło Cieszyna, ks. dr Karol Mozor.

Przedstawiciele Kościołów rzymskokatolickiego i ewangelickoaugsburskiego uczestniczyli w ekumenicznych sympozjach i konferencjach naukowych odbywających się zarówno w Uniwersytecie Śląskim w Cieszynie jak i w Instytucie Teologicznym im. Świętego Jana Kantego w Bielsku-Białej ${ }^{39}$.

W październiku 2000 roku odbyło się w ewangelickim Ośrodku Wydawniczym „Augustana” sympozjum naukowe pod hasłem „Chrystus i Jego Kościół”. Zorganizowała go diecezja cieszyńska Kościoła ewangelicko-augsburskiego oraz diecezja bielsko-żywiecka Kościoła rzymskokatolickiego. Rozpoczynając nabożeństwo, gospodarz parafii i biskup diecezji cieszyńskiej Kościoła ewangelicko-augsburskiego Paweł Anweiler powiedział: „Nie zagubmy nigdy Jezusa Chrystusa, który jest niezbędny dla naszego życia, nie dajmy sobie zaciemnić obrazu Tego, który stanowi światło w nas i naszych Kościołach”. Na zakończenie sympozjum (31 października 2000) odprawiono w ewangelicko-augsburskim kościele Zbawiciela w Bielsku-Białej nabożeństwo ekumeniczne. Biskup Tadeusz Rakoczy zwracając się do uczestników nabożeństwa powiedział m.in.:

39 Miedzy innymi: w październiku 1996 roku odbyła się konferencja międzynarodowa „Stosunki wyznaniowe na Śląsku Cieszyńskim”; w 1998 roku sesja naukowa „Szansa, czy zagrożenie dla polskich pograniczy”; w 2000 roku sesja naukowa „Pojednajcie się. Pastoralny i społeczno-kulturowy wymiar ekumenizmu na Śląsku Cieszyńskim”; w 2001 roku sesja naukowa „Z Duchem Świętym w trzecie tysiąclecie”; w 2003 roku „Sekty i nowe ruchy religijne - studium ekumeniczne”. Por. ibidem, s. 163-172. 
Dziękuję Bogu i ludziom, że w Jubileuszowym Roku 2000 w naszym mieście odbyło się sympozjum, poświęcone jedności chrześcijan, które pozwala nam ciągle lepiej się poznawać, usuwać wzajemne uprzedzenia, przybliżać się do siebie i wzrastać w Chrystusie ku pełnej jedności ${ }^{40}$.

\section{Ekumenizm praktyczny (społeczno-kulturowy)}

Praktyczny ekumenizm wyraża się przede wszystkim w działalności społeczno-kulturowej, czego przykładem jest Amatorski Zespół Teatralny przy parafii św. Elżbiety w Cieszynie działający od 1975 roku. Ma on na celu nie tylko pielęgnowanie kultury żywego słowa, lecz przede wszystkim pragnie stworzyć, poprzez przedstawienia, wspólnotę przeżywającą Ewangelię, która zarówno od strony aktorów i od strony widzów nie dokonuje podziałów. W 1984 roku zrodziła się myśl inscenizacji Drogi Krzyżowej - Męki Pańskiej, Jasełek i Gościa Oczekiwanego Zofii Kossak. Prowadząca Zespół od początku s. Jadwiga zgromadziła ponad sto osób - są to dzieci, młodzież, studenci i dorośli. Aktorzy - amatorzy - wywodzą się ze środowisk katolickich i ewangelickich.

Panorama Sztuki Chrześcijańskiej Musica Sacra to kolejna inicjatywa ekumeniczna, która organizowana jest co roku dla upamiętnienia historycznego pobytu w Skoczowie - 22 maja 1995 roku - Papieża Jana Pawła II. Idea zorganizowania tego festiwalu zrodziła się niespełna rok po wizycie w Skoczowie na Kaplicówce Jana Pawła II. Jeden ze współorganizatorów Panoramy, Ludwik Herok, stwierdził, że motywacją tego kulturalnego i religijnego wydarzenia była nie tylko wizyta Papieża w mieście narodzin św. Jana Sarkandra, ale również to, by

festiwal posiadał charakter ekumeniczny, a koncerty odbywały się na przemian w kościele katolickim i ewangelickim (...) Chcemy, aby Stowarzyszenie Musica Sacra (powołane w 1999 roku) zbliżało ludzi i wzmacniało ich wrażliwość. Najlepszą płaszczyzną dla wzajemnego zrozumienia jest sztuka. Dlatego chcemy promować sztukę i kulturę chrześcijańską ${ }^{41}$.

Dożynki ekumeniczne to kolejna płaszczyzna pastoralno-kulturowa w procesie zjednoczeniowym. Tradycja takich dożynek zapoczątkowana została w Polsce, w Brennej w 1990 roku. Z inicjatywy proboszcza katolickiej parafii w Brennej ks. Józefa Budniaka i przy współpracy proboszcza parafii ewangelickiej ks. Erwina Miklera oraz wójta Gminy Brenna, coroczne dożynki, organizowane pierwotnie jako święto

40 W archiwum własnym autora. Syg. JB/31 X 2000/SiNE, 2.

$41 \quad$ Musica Sacra tuż, „Głos Ziemi Cieszyńskiej” 2005, nr 19. 
ludowe, przemieniły się w święto religijno-ludowe. Głównym celem tego działania miała być integracja wielowyznaniowych mieszkańców gminy wokół wspólnych nie tylko tradycji kulturowych, ale także wspólnych treści religijnych. Ekumeniczne dożynki odbywają się co roku w ostatnią niedzielę sierpnia. Uroczystość dopełniają występy chórów katolickiego i ewangelickiego nie tylko z Brennej, ale również z Ustronia i z Republiki Czeskiej. Nabożeństwo kończy wspólne błogosławieństwo. Gośćmi dożynkowego święta są księża biskupi - katoliccy i ewangeliccy, duchowni z kraju i z zagranicy, przedstawiciele władz miejscowych i wojewódzkich, parlamentarzyści oraz przedstawiciele świata nauki i kultury regionu śląskiego. Ekumeniczne dożynki w 2000 roku potwierdzają tezę o coraz szerszym zasięgu tej inicjatywy - obok tradycyjnie uczestniczących przedstawicieli Kościołów rzymskokatolickiego, ewangelicko-augsburskiego i prawosławnego po raz pierwszy udział w tym wydarzeniu wziął zwierzchnik Kościoła ewangelicko-reformowanego w Polsce. Ponadto przesłanie do uczestników dożynek przekazał na piśmie Prezydent RP.

Ekumeniczne dożynki w Brennej stały się inspiracją do organizowania podobnych uroczystości w innych miejscowościach na Śląsku Cieszyńskim. Na przykład, w pierwszą niedzielę września 1999 roku w Ustroniu i w Jaworzu odbyły się po raz pierwszy uroczystości, podobnie jak w Brennej, nazwane ekumenicznymi dożynkami ${ }^{42}$. Ekumeniczne dziękczynienie za plony przekroczyło granice Ziemi Cieszyńskiej - we wrześniu 2000 roku, w miejscowości Ryboły na wschodnim pograniczu Polski odbyły się pierwsze katolicko-prawosławne dożynki, a w pierwszym roku trzeciego tysiąclecia (wrzesień 2001 roku) po raz pierwszy odbyły się dożynki ekumeniczne w Lasowicach na Śląsku Opolskim.

Nietypową formą ruchu ekumenicznego, z którą można spotkać się tylko na Śląsku Cieszyńskim jest działalność kulturalno-oświatowa realizowana w postaci ekumenicznych klubów i kółek zainteresowań, skierowana do dzieci i młodzieży katolickiej i ewangelickiej. Prowadzi ją od września 1998 roku swoiste centrum kultury przy Kościele ewangelickim w Brennej. Tu działa kółko modelarskie, klub szachowy, klub tenisa stołowego, dziecięce kółko plastyczne i poetyckie, prowadzone przez wykwalifikowanych instruktorów i pedagogów. Dla pań zorganizowano zajęcia aerobiku.

Głównym celem tych działań jest integracja środowiska, a także rozwijanie zainteresowań kulturalnych dzieci bez względu na ich

42 Dożynki, [w:] I. Brudny, M. Pilsyk, E. Pyka, T. Sieroń (red.),Byliśmy, jesteśmy i będziemy mieszkańcami Śląska Cieszyńskiego, Jasienica 2001, s. 63-64. 
wyznanie i otoczenie ich opieką w czasie wolnym. Ważną funkcją jest także kształtowanie u dzieci i młodzieży postaw proekumenicznych, otwartości na wszelkiego rodzaju odmienności kulturowe. Znaczenie także ma fakt, że zajęcia te gromadzą dzieci wokół parafii, z którą częściowo utraciły kontakt w wyniku przeniesienia religii do szkół ${ }^{43}$.

W różnych instytucjach kulturalno-oświatowych na Śląsku Cieszyńskim mają miejsce działania kulturalne, które opatrzono tu nazwą „ekumeniczne wystawy”, a które dotyczą przede wszystkim prezentacji książek, czasopism, plakatów i fotografii dotykających zagadnień ekumenicznych. Oto dwa przykłady takich inicjatyw.

8 listopada 1999 roku w Książnicy Beskidzkiej w Bielsku-Białej nastąpiło otwarcie wystawy „Abyśmy byli jedno”, dedykowanej wielkiemu orędownikowi pojednania, Ojcu Świętemu Janowi Pawłowi II. Już sama obecność ordynariusza diecezji bielsko-żywieckiej bp Tadeusza Rakoczego oraz luterańskiego biskupa cieszyńskiego Pawła Anweilera świadczy o jej ekumenicznym charakterze. Na wystawie zaprezentowano wydawnictwa biblijne i ekumeniczne Kościołów rzymskokatolickiego i ewangelicko-augsburskiego. Na szczególną uwagę zasługują starodruki ze zbiorów Książnicy Beskidzkiej: Biblia Sacra. Księgi Starego i Nowego Testamentu (Brzeg Śląski 1768), Biblia ks. Marcina Lutra (Norymberga 1797), Kazania na Niedziele Całego Roku ks. Piotra Skargi (Sandomierz 1792), cenne wydawnictwa XIX-wieczne oraz współczesne wydawnictwa Kościołów katolickiego i ewangelickiego, takie jak Biblia Tysiaclecia drukowana oraz w wersji elektronicznej na płycie CD-ROM, Ilustrowany Nowy Testament i inne. Ekspozycja została wzbogacona zdjęciami z dożynek w Brennej oraz z XXVIII Międzynarodowego Kongresu Ekumenicznego w Cieszynie (1995).

Druga wystawa o podobnym profilu otwarta została w marcu 2000 roku, z okazji sesji naukowej pt. „Pastoralny i społeczno-kulturowy wymiar ekumenizmu na Śląsku Cieszyńskim”. Wystawę tę, zatytułowaną „Polska książka katolicka i ewangelicka w walce o kształt społeczno-kulturowy Śląska Cieszyńskiego”, przygotowała kustosz Biblioteki Tschammera w Cieszynie, mieszczącej się przy ewangelickim kościele Jezusowym. Wystawa prezentowała zdjęcia stron tytułowych książek od XVII do początków XX wieku, które związane są z Ziemią Cieszyńską poprzez miejsce wydania lub osobę autora. Znalazły się tu Biblie dwóch wyznań w języku polskim, książki religijne, pierwodruki cieszyńskie, kancjonały katolickie i ewangelickie, książki modlitewne poświęcone kształceniu młodzieży. Celem wystawy, jak stwierdziła jej 
organizatorka, było „uświadomienie zwiedzającym, że katolicy i ewandialogu gelicy, nawet jeśli nie działali wspólnie, dążyli do tych samych celów i byli świadomi, że wszelkie podziały dzielą i powodują, że wszyscy tracą"44.

Pięć lat po ogłoszeniu Dekretu Soborowego o Ekumenizmie, w dniu 11 maja 1968 roku została poświęcona świątynia katolicka w Drogomyślu na Śląsku Cieszyńskim. Konsekracji dokonał ordynariusz diecezji katowickiej bp Herbert Bednorz. Przy budowie kościoła brali udział zarówno katolicy, jak i ewangelicy mieszkający w Drogomyślu, a w uroczystości poświęcenia świątyni uczestniczyli duchowni i wierni obu wyznań. Podobne zaangażowanie ekumeniczne przy budowie świątyni katolickiej, a następnie przy jej poświęceniu było w Ustroniu-Polanie (25.11.1989); Cieszynie-Mnisztwie (28.11.1992) i w Brennej (27.11.1993)

Podobny charakter miały poświęcenia kościołów luterańskich. W 1989 roku poświęcony został kościół w Brennej, którego to aktu dokonał biskup Kościoła Ewangelicko-Augsburskiego w RP, Jan Szarek. Kościół katolicki reprezentował wraz ze swymi wiernymi proboszcz parafii katolickiej w Brennej.

Księża katoliccy i wierni Kościoła rzymskokatolickiego uczestniczyli również w uroczystościach poświęcenia nowych kościołów luterańskich w Wiśle, Marklowicach i Cisownicy.

W ostatnich latach powstało na Śląsku Cieszyńskim oprócz wielu nowych kościołów również wiele kaplic, a wśród nich kilka w szpitalach i sanatoriach. Ze względu na różnorodność wyznaniową przebywających w tych miejscach osób mają one z założenia charakter ekumeniczny, i taki też wymiar miały uroczystości ich poświęcenia. Biskupi Kościołów katolickiego i ewangelickiego dokonywali poświęcenia tych kaplic.

W 1986 roku została poświęcona kaplica ekumeniczna w Śląskim Szpitalu Reumatologiczno-Rehabilitacyjnym im. gen. Jerzego Ziętka w Ustroniu. Aktu poświęcenia dokonał bp Damian Zimoń, ordynariusz diecezji katowickiej oraz proboszcz parafii ewangelicko-augsburskiej ks. dr Henryk Czembor. A rok później, 3 września, została poświęcona, przez tych samych duchownych kaplica ekumeniczna pw. Opatrzności Bożej w Szpitalu Uzdrowiskowym w tej samej miejscowości ${ }^{45}$.

44 G. Ciompa-Wucka, Informacja o wystawie ksiązki, [w:] J. Budniak, H. Rusek (red.), Pojednajcie się... Materiaty z sesji naukowej: Pastoralny i społeczno-kulturowy wymiar ekumenizmu na Ślasku Cieszyńskim, Cieszyn 2000, s. 242.

45 Na podstawie „Kroniki” szpitalnej i uzdrowiskowej informacje przekazał kapelan szpitalny ks. Jan Piszczan. 
W kaplicy ekumenicznej Szpitala Uzdrowiskowego w Ustroniu w maju 1991 roku odbyło się Międzynarodowe Spotkanie Ekumeniczne z udziałem katolików i protestantów z Polski i Niemiec ${ }^{46}$. Liturgia Słowa Teologia dialogu Bożego była prowadzona przez proboszczów ustrońskich, katolickiego - ks. Leopolda Zielasko oraz luterańskiego - ks. dr H. Czembora.

4 kwietnia 1997 roku w Szpitalu Śląskim w Cieszynie odbyła się uroczystość poświęcenia nowej kaplicy, która ma charakter ekumeniczny, bowiem służy zarówno katolikom, jak i ewangelikom ${ }^{47}$. Formułę poświęcenia odmówili biskup katolicki Tadeusz Rakoczy i biskup ewangelicki Paweł Anweiler. Msze św. odprawiane są tu codziennie i w niedzielę rano, a nabożeństwa luterańskie w każdą niedzielę przed południem oraz $\mathrm{w}$ poniedziałki.

Na początku 2001 roku, 18 stycznia, księża biskupi, T. Rakoczy i P. Anweiler, poświęcili Śląskie Centrum Rehabilitacji „Szpital z Sercem" w Ustroniu Zawodziu ${ }^{48}$.

Podobne wydarzenie miało miejsce 21 marca 2001 roku, kiedy została poświęcona przez biskupów katolickiego i ewangelickiego kaplica ekumeniczna w Wojewódzkim Szpitalu w Bielsku-Białej. W kaplicy tej odbywają się regularnie Msze św. i nabożeństwa, osobno dla katolików i ewangelików. Szczególnym rysem ekumenicznym obrzędów liturgicznych jest wykorzystywanie w nich tych samych „naczyń liturgicznych” (kielicha mszalnego, pateny, puszki na komunikanty), ofiarowanych przez cieszyńskiego biskupa luterańskiego P. Anweilera.

Jak widać z przytoczonych wyżej przykładów, kaplice ekumeniczne powstają na Ziemi Cieszyńskiej we wszystkich ważnych instytucjach społecznych, pełniących swe funkcje wobec mieszkańców regionu bez względu na ich przynależność wyznaniową

We wszystkich opisanych kaplicach, oprócz regularnie celebrowanych nabożeństw, w Tygodniu Modlitw o Jedność Chrześcijan odbywają się nabożeństwa ekumeniczne z udziałem duchownych i wiernych obu wyznań.

Kolejnym przykładem działalności społeczno-kulturowej jest grupa artystyczna młodych ludzi z Cieszyna, z Kościołów rzymskokatolickiego i ewangelicko-augsburskiego, która od marca 1998 roku przyjęła nazwę Zespół Teatralny. Inicjatorami takiej formy budowania pojednania między dwoma wyznaniami chrześcijańskimi byli ks. Mirosław Szewieczek, wikariusz parafii katolickiej św. Marii Magdaleny w Cieszynie

\footnotetext{
$46 \quad$ Ibidem.

47 Zob. M. Fres, Poświęcenie kaplicy szpitalnej, „Dziedzictwo” (Miesięcznik Religijno-Społeczny Ziemi Cieszyńskiej), 1995, nr 5 (43), s. 3.

48 Szpital pod Równica, „Głos Ziemi Cieszyńskiej” 2001, nr 4.
} 
i ks. Alfred Borski, wikariusz parafii ewangelickiej w Cieszynie. Zespół ten przygotował sztukę Widziatam Pana ... czyli petna życia wizja nawrócenia grzesznicy - Marii Magdaleny. Premiera tej sztuki w formie: światło, muzyka, pantomima, słowo, odbyła się w Cieszynie 16 maja 1998 roku w kościele Jezusowym (ewangelickim), a w następnym dniu w Kościele katolickim św. Marii Magdaleny. Sztukę tę oprócz Cieszyna wystawiano w różnych miejscowościach, m.in. w Warszawie, Lublinie, Brennej. Na zaproszenie katolickiego ruchu „Focolari” Zespół występował we Włoszech. Wspólne próby i przedstawienia w duchu radosnej współpracy to najlepsze świadectwo ekumenizmu, jakie składają członkowie Zespołu Teatralnego z Cieszyna.

Młodzieżowa grupa ewangelizacyjna z Cieszyna zorganizowała w dniach od 11 do 13 maja 2000 roku Święto Radości - Ewangelizacja „Cieszyn 2000”. Podczas tej Ewangelizacji koncertowały zespoły muzyki chrześcijańskiej, a wśród nich chór dziecięcy „Hosanna” z parafii ewangelicko-augsburskiej w Cieszynie.

$\mathrm{Na}$ Śląsku Cieszyńskim odbywa się od 1999 roku Festiwal Twórczości Religijnej „Psallite Deo”. Impreza odbywa się pod patronatem ordynariusza diecezji bielsko-żywieckiej oraz zwierzchnika diecezji cieszyńskiej Kościoła ewangelicko-augsburskiego, ordynariusza diecezji łódzko-poznańskiej Autokefalicznego Kościoła Prawosławnego, oraz biskupa Kościoła ewangelicko-reformowanego w Polsce. Ta impreza kulturalna i muzyczna posiada charakter ekumeniczny, a koncerty odbywają się w kościołach katolickich i ewangelickich.

W lipcu 2004 i 2006 roku odbyło się w Wiśle na Śląsku Cieszyńskim ekumeniczne spotkanie w ramach Festiwalu Życia adresowane do całej społeczności należącej do różnych Kościołów i wspólnot chrześcijańskich. Idea festiwalu opiera się na współdziałaniu chrześcijan, niezależnie od wyznania, którzy chcą aktywnie dzielić się Bożą miłością z innymi. Co rano festiwalowe zajęcia rozpoczynała wspólna modlitwa. W ramach festiwalu odbywały się liczne happeningi, dramy, pantomimy, koncerty, warsztaty muzyki gospel, zajęcia dla najmłodszych - igrzyska dziecięce Kids Games, panele dyskusyjne, spotkania dla uzależnionych od alkoholu czy narkotyków, pokazy sportów ekstremalnych, prezentacje chrześcijańskich wydawnictw i wystawy. Panele i seminaria stanowiły forum dyskusyjne dla problemów, które niesie z sobą współczesna Europa ${ }^{49}$.

Od ogłoszenia w Polsce stanu wojennego 13 grudnia 1981 roku Kościoły i Wspólnoty chrześcijańskie w Polsce, razem podjęły ekumeniczną działalność pomocy wszystkim poszkodowanym, a szczególnie

$49 \quad$ Por. www.festiwalzycia.ccm.pl (z 12 sierpnia 2006 roku). 
osobom, które znalazły się w więzieniach i ośrodkach internowania. Począwszy od skromnych paczek spożywczych do lekarstw, Kościoły okazywały wielką pomoc. Kościół podejmując tę działalność idzie za przykładem Jezusa „dobrego Samarytanina” (Łk 10, 29-37) i z „Niego czerpiąc swoją moc, stał zawsze w pierwszej linii na wszystkich tych frontach działalności charytatywnej" ${ }^{50}$. Od tego okresu rozpoczęła się wspólna służba i bezinteresowna troska o najbardziej potrzebujących (1994). Między innymi zrodziło się Ekumeniczne Wigilijne Dzieło Pomocy Dzieciom, w skład którego wchodzą: Caritas Polska Kościoła Rzymskokatolickiego i Prawosławne Dzieło Miłosierdzia Eleos oraz Diakonia Kościoła Ewangelicko-Augsburskiego. Inauguracja tego dzieła rozpoczyna się co roku w I Niedzielę Adwentu.. W roku 2009 dołączyła do tego dzieła Diakonia Kościoła Ewangelicko-Reformowanego.

Akcja charytatywna Ekumeniczne Wigilijne Dzieło Pomocy Dzieciom pragnie szczególnie zwrócić uwagę na aspekt rodziny i sieroctwa, zarówno naturalnego, jak i społecznego; wspiera projekty na rzecz dzieci i młodzieży w trudnej sytuacji materialnej: dożywianie dzieci w szkołach, zakup odzieży i podręczników szkolnych, dofinansowanie przejazdów szkolnych. Środki zebrane z rozprowadzania świec przeznaczone są na wsparcie tych projektów na poziomie diecezjalnym, jak i ogólnopolskim.

Ekumeniczne Wigilijne Dzieło Pomocy Dzieciom stało się świąteczną tradycją. Zapalona świeca wigilijna to znak chrześcijańskiej solidarności i gotowości, by dzielić się tym światłem, swoim zainteresowaniem i tym, co możemy dla innych zrobić.

Przykładem ekumenicznej wrażliwości na pomoc potrzebującym była zbiórka pieniężna dla ofiar kataklizmu prowadzona przez Caritas Polska, ewangelicką Diakonię i Prawosławne Dzieło Miłosierdzia Eleos w związku z trzęsieniem ziemi i tsunami, które dotknęły Japonię.

Kościoły uważają, że

orędzie społeczne Ewangelii nie powinno być traktowane jako teoria, ale przede wszystkim jako podstawa działania i zachęta do niego. Pod wpływem tego orędzia niektórzy z pierwszych chrześcijan rozdawali swe dobra ubogim, dając świadectwo, że nawet między ludźmi różnego pochodzenia społecznego możliwe jest pokojowe i solidarne współżycie. Czerpiąc w ciągu wieków moc z Ewangelii, mnisi uprawiali ziemię, zakonnicy i zakonnice zakładali szpitale i przytułki dla ubogich, członkowie bractw religijnych oraz mężczyźni i kobiety wszelkiego stanu nieśli pomoc ludziom potrzebującym i upośledzonym społecznie, przekonani, że słowa Chrystusa: „Wszystko, co uczyniliście jednemu z tych braci moich 
najmniejszych, Mnieście uczynili” (Mt 25, 40), nie powinny pozostawać pobożnym życzeniem, ale muszą skłaniać do konkretnego działania ${ }^{51}$.

Działalność Kościołów chrześcijańskich na początku trzeciego tysiąclecia pozwala stwierdzić, że weszły one na drogę pojednania, a tysiąclecie to zapowiada się jako epoka poszukiwania nowych dróg i płaszczyzn zbliżania się do siebie. Papież Jan Paweł II kładł mocny akcent na dialog ekumeniczny, który należy

zdecydowanie kontynuować, nie ustępując wobec trudności i przeciwieństw; należy go prowadzić «w różnych wymiarach - doktrynalnym, duchowym i praktycznym - kierując się logiką wymiany darów, które Duch wzbudza w każdym Kościele, oraz wychowując wspólnoty i wiernych, przede wszystkim młodych, do przeżywania spotkania i właściwie rozumianego ekumenizmu jako zwykłego wymiaru życia i działalności Kościoła». Dialog ten stanowi jedno z głównych zadań Kościoła, przede wszystkim tu, w Europie, która w minionym tysiącleciu była świadkiem zbyt wielu podziałów między chrześcijanami, a dziś zdąża ku ściślejszej jedności. Nie możemy zatrzymać się na tej drodze, nie możemy z niej zawrócić! Musimy nadal nią iść i przeżywać ją ufnie, bo wzajemny szacunek, szukanie prawdy, współpraca w miłości, a przede wszystkim ekumenizm świętości niewątpliwie przyniosą, z Bożą pomocą, swoje owoce $^{52}$.

Podsumowując przedstawione rozważania podkreślić należy, że ekumeniczna otwartość mieszkańców tej części Śląska ma swoje wiekowe ugruntowanie. Od XVI stulecia do czasów współczesnych żyli tu zgodnie ewangelicy i katolicy oraz Żydzi. Na początku trzeciego tysiąclecia można za ewangelicko-reformowanym teologiem ze Szwajcarii, Karlem Barthem, przyjąć tezę, że „choć wierzymy inaczej, nie wierzymy jednak w Innego". Każdemu należy się szacunek wobec jego wiary i wyznawanych wartości.

Śląsk Cieszyński zawsze kojarzył się ze szczególną syntezą tego, co chrześcijańskie. Od stuleci był kolebką wiary i miłości Boga. Cieszyn, jako stolica tego regionu, jest miastem, w którym ekumenizm, nie ten teologiczny, ale ekumenizm praktyczny, codzienny, wypełnia życie mieszkańców. Historyczne uwarunkowania sprawiły, że tu na tej ziemi działali duchowni i świeccy, dla których dobro ludzi, pomoc bliźniemu będącemu w potrzebie, rozwój stolicy księstwa na płaszczyźnie

\footnotetext{
$51 \quad$ Ibidem, nr 57.

52 Jan Paweł II, Posynodalna adhortacja apostolska Ecclesia in Europa, 31.
} 
społecznej, ekonomicznej i intelektualnej stawały się celami działania. Dzisiaj w widoczny sposób przemawiają do wszystkich tradycja, świadectwo dziejów, dziedzictwo kultury i nauki, związane z tym miastem. Mieszkańcy tej ziemi w szczególny sposób kultywują wielki dar jedności, który został im dany w duchu miłości Bożej. Inicjatywy społeczne i kulturalne są możliwe dzięki wielkiemu zaangażowaniu katolików i ewangelików, którym przyświeca idea rozwoju tego specyficznego miejsca.

Na Śląsku Cieszyńskim, gdzie „ekumenizm jest sprawą życia społecznego" ${ }^{53}$, coraz bardziej upowszechnia się świadomość ekumeniczna i wydaje się, że region ten może być dla Europy, pod względem pracy ekumenicznej we wszystkich jej wymiarach, wzorem godnym naśladowania.

Słowa kluczowe: Śląsk Cieszyński, diecezja bielsko-żywiecka, ekumenizm, inicjatywy ekumeniczne, Kościół katolicki, Kościół ewangelicko-augsburski.

\section{Bibliografia:}

1. Bilczewski J., O Kościele Chrystusowym, Cieszyn 1908.

2. Borutka T., Diecezja Bielsko-Żywiecka 1992-1997, Bielsko-Biała 1997.

3. Brenna jak Asyż, „Głos Ziemi Cieszyńskiej” Cieszyn 22 III 2002.

4. Budniak J., Ekumenizm jutra na przykładzie Ślaska Cieszyńskiego Studium historyczno-pastoralne, Katowice 2002.

5. Budniak J., Ekumenizm na granicy, [w:] J. Kempa (red.), Kościót wobec granic, Katowice 2005.

6. Budniak J., Ekumenizm na Ślasku Cieszyńskim na przełomie wieków, [w:] Pojednajcie sie ....

7. Budniak J., Kaplica ekumeniczna w filii Uniwersytetu Śląskiego w Cieszynie. Powrót do tradycji. „Śląskie Studia Historyczno-Teologiczne” 1998, nr XXXI.

8. Budniak J., Sesja na temat Ekumenicznych Dni Biblijnych, „Biuletyn Ekumeniczny" 1998, nr 17.

9. Budniak J., W trzecie tysiaclecie ku, ,petnej komunii”, [w:] J. Budniak, M. J. Uglorz (red.), Z Duchem Świętym w trzecie tysiaclecie, Cieszyn 2001.

10. Budniak J., XXVIII Międzynarodowy Kongres Ekumeniczny w Cieszynie, Cieszyn-Bytom 1996.

53 Zdanie to wypowiedział bp Tadeusz Rakoczy na początku wywiadu, jaki przeprowadził z nim moderator Telewizji Polskiej w dniu 21 sierpnia 1995 roku, podczas inauguracji XXVIII Międzynarodowego Kongresu Ekumenicznego w Cieszynie. Por. J. Budniak, XXVIII Międzynarodowy Kongres Ekumeniczny $w$ Cieszynie, Cieszyn-Bytom 1996, s. 35. 
11. Celebrationes liturgicae. Quibus praeest Summus Pontifex Johannes Paulus PP II, Olomouc 21 maii 1995.

12. Ciompa-Wucka G., Informacja o wystawie ksiażki, [w:] J. Budniak, H. Rusek (red.), Pojednajcie sie ... Materiaty z sesji naukowej: Pastoralny i spoŁeczno-kulturowy wymiar ekumenizmu na Ślasku Cieszyńskim, Cieszyn 2000.

13. Dożynki, [w:] I. Brudny, M. Pilsyk, E. Pyka, T. Sieroń (red.), Byliśmy, jesteśmy i będziemy mieszkańcami Ślaska Cieszyńskiego, Jasienica 2001.

14. Dyrektorium w sprawie realizacji zasad i norm dotyczacych ekumenizmu (25.03.1993), „Communio” 1994, 2 (80).

15. Fres M., Poświęcenie kaplicy szpitalnej „Dziedzictwo” „Miesięcznik Religijno-Społeczny Ziemi Cieszyńskiej" 1995, nr 5 (43).

16. Glaeser Z., Ekumeniczne przyzywanie Ducha Świętego. Refleksje na marginesie ekumenicznych spotkań chrześcijan w diecezji opolskiej, „Biuletyn Ekumeniczny" 1999, nr 2.

17. Homilia Ojca Świętego Jana Pawła II wygłoszona podczas kanonizacji św. Jana Sarkandra w Otomuńcu - 21 maja 1995 roku.

18. Jan Paweł II, encyklika Evangelium vitae.

19. Jan Paweł II, Jak budować pokój? (Przemówienie wygłoszone 14 kwietnia 2003 roku do uczestników Kongresu UNIV), „L'Osservatore Romano” wydanie polskie 2003, 6 (254).

20. Jan Paweł II, Posynodalna adhortacja apostolska „Ecclesia in Europa”.

21. Jan Paweł II, Przemówienie wygłoszone $w$ czasie spotkania $z$ wiernymi $w$ kościele ewangelicko-augsburskim w Skoczowie, [w:] Drogowskazy dla Polaków Ojca Świętego Jana Pawła II, Kraków 1999, t. 3.

22. Jan Paweł II, Wstańcie, chodźmy. Cz.1. Powołanie. „L'Osservatore Romano” wydanie polskie 2004, nr 7-8 (265).

23. Legendź M., Ustyszałem alarm i pobiegłem, „Zwiastun” 2000, nr 4.

24. Misiaszek A., Teologia pastoralna. Gdańsk 1994.

25. Musica Sacra tu̇̇, „Głos Ziemi Cieszyńskiej” 2005, nr 19.

26. Pikus T., Program ekumeniczny Jana Pawła II w encyklice „Ut unum sint”, [w:] S. Pawłowski (red.), Różnić się w zgodzie, Lublin 2008.

27. Plinta D. A., Legendź M., Parafia z wyobraźnia - inicjatywy i pomysty w Brennej, ,Zwiastun”1999, nr 12.

28. Rakoczy T., List do wiernych w zwiazku z Tygodniem Ekumenicznym, „Kwartalnik Diecezjalny” 1993, nr 1-2.

29. Stowo Księdza Biskupa Tadeusza Rakoczego podczas ingresu do katedry św. Mikołaja w Bielsku-Białej. „Kwartalnik Diecezjalny” (Pismo Urzędowe Diecezji Bielsko-Żywieckiej) 1992, nr 1.

30. Szpital pod Równica, „Głos Ziemi Cieszyńskiej” 2001, nr 4.

31. Trwać razem we wspólnocie. Ekumeniczne spotkania modlitewne w katedrze św. Mikołaja w Bielsku-Białej w latach 1984-2012, oprac. B. Mebel, Z. Gebauer, Bielsko-Biała 2012. 